\title{
ANALISIS STRATEGI ISLAMIC COLLECTIVE ENTREPRENEURSHIP (ICE): SOLUSI MENGATASI DESA TERTINGGAL
}

\author{
Dzaky Adam Thamrin, Boby Habibi, Dewi Permata Sari, Fauzul Hanif Noor Athief \\ Hukum Ekonomi Syariah Universitas Muhammadiyah Surakarta \\ E-Mail: dzakythamrin94@gmail.com, bobyhabibie99@gmail.com, i000160133@ums. \\ ac.id, fauzul.hanif@ums.ac.id
}

\begin{abstract}
Abstrak: Sektor ekonomi desa memiliki peran substansial bagi kesejahteraan masyarakat dan menjadi tulang punggung perekonomian nasional. Data Kementerian Desa (2018) menunjukkan masih ada 13.232 desa tertinggal karena faktor ekonomi. Adapun kendala besar dalam ketertinggalan desa adalah rendahnya Sumber Daya Manusia (SDM), sehingga dibutuhkan upaya untuk meningkatkan SDM pada desa salah satunya dengan berwirausaha. Hal ini telah dilakukan oleh Desa Gerdu yang berhasil menjadi Desa Wisata Islami. Strategi wirausaha dilakukan secara kolektif yang berlandaskan nilai-nilai Islam atau dikenal Islamic Collective Entrepreneurship (ICE). Peneliti mencoba mengangkat sejauh mana strategi ICE dapat menjadi solusi dalam membangun perekonomian desa, sehingga strategi ini dapat menjadi solusi bagi desa tertinggal lainnya. Penelitian menggunakan metode deskriptif kualitatif dan observasi dalam pengumpulan data. Data tersebut diperoleh dari hasil wawancara yang akan dilaksanakan dengan informan dari pemuka masyarakat, perwakilan masyarakat, dan instansi kabupaten. Dari hasil analisa, strategi ICE yang dilakukan Desa Gerdu memiliki 3 (tiga) tahap yaitu: 1. Pendidikan dan Kerjasama, 2. Pelaksanaan dan Pengelolaan, 3. Evaluasi dan Perencanaan. Selain itu, faktor pendorong internal dalam kesuksesan ICE terletak pada keaktifan pemuka dan pemuda desa dalam mempraktikkan ekonomi Islam. Adapun kerjasama dengan pihak eksternal seperti BAZNAS, DISPARPORA, serta lembaga lainnya sekitar desa yang aktif membantu dalam pembangunan desa.
\end{abstract}

Kata kunci: Desa tertinggal, Ekonomi Desa, ICE, Wirausaha

Abstract: The rural economic sector has a substansial role for the welfare of society and the economic support of nation. Data from Indonesian Ministry of Villages (2018) showed 13.232 underdeveloped villages in Indonesia due to economic reasons. The lack of human resources was the major reason. Therfore, the improvement of human resources throught entrepreneurship is needed. One of the successful village throught entrepreneurship is Gerdu Village in Karanganyar, which also has succeeded in becoming an islamic tourism village. The entrepreneurship strategy is carried out collectively based on islamic values or known as islamic Collective Entrepreneurship (ICE). Researchers try to find how far the effecticeness of ICE strategy as a solution for othe underdeveloped villages. This is a descriptive qualitative research with using observation for collecting data. The data is obtained through interviews with some informants: community leader, community representative, and district institution in Karanganyar. The result is the ICE strategy was carried out by Gerdu Village has three stages: 1. Education and Cooperation, 2. Implementation and Management, 3. Evaluation and Planning. In addition, the internal driving factor in ICE's success lies in the activeness of village leader and youth in practicing islamic economics. The collaborationwith external parties such as BAZNAS, 
DISPARPORA, as well as other intitution around the village are actively helping in village development.

Keyword: Entrepreneurship, ICE, Underdeveloped Village, Village Economic

\section{PENDAHULUAN}

Data Badan Pusat Statistik (BPS) menunjukkan bahwa total penduduk Indonesia yang tinggal di desa tahun 2019 sebesar $33,4 \%$ dari seluruh penduduk Indonesia. Sepertiga penduduk Indonesia tinggal di pedesaan yang jumlahnya menurun setiap tahun. Millary (2019) menyebutkan penurunan tersebut dikarenakan urbanisasi. Terjadinya urbanisasi disebabkan keinginan masyarakat desa untuk mendapatkan standar taraf hidup yang lebih tinggi. Namun kondisi desa masih tertinggal secara ekonomi seperti halnya kemiskinan, standar hidup yang rendah dan minimnya infrastruktur desa. Oleh karena itu, perpindahan menuju kota masih menjadi solusi untuk menaikkan taraf hidup masyarakat desa.

Dalam menaikkan taraf hidup desa di Indonesia, pemerintah pusat telah mengucurkan dana sebesar 189 triliun rupiah sejak tahun 2015 untuk setiap desa di Indonesia. Dalam tiga tahun pelaksanaannya, data Kementerian Desa (2018) menunjukkan masih ada 13.232 desa tertinggal. Salah satunya disebabkan faktor ekonomi yang belum dimaksimalkan potensinya terutama potensi SDM desa.

Dilihatdarigeografis, desa merupakan daerah yang mempunyai potensi ladang bisnis yang menguntungkan, karena wilayahnya yang bersifat agraris dan bergantung pada alam memiliki lahan yang lebih terbuka daripada kota. Ray (2013) mengungkapkan bahwa berbagai potensi dan berlimpahnya sumber daya alam (SDA) yang tersedia menjadikan dukungan tersendiri untuk pelaku usaha memperoleh bahan baku sesuai dengan bidang usaha yang ditekuninya. Hal ini dapat dikatakan jika potensi desa juga bergantung dari potensi yang ada pada sumber daya alam yang ditawarkan di desa tersebut untuk melakukan usaha.

Tak hanya itu, berwirausaha dalam desa memiliki peluang yang besar, terutama berwirausaha melalui produk unggulan yaitu bidang pertanian dan wisata. Melihat dari ulasan yang ada, maka penguatan potensi desa merupakan hal yang penting dilakukan saat ini. Hal ini sejalan dengan pandangan bahwa sektor ekonomi desa dapat menjadi tulang punggung perekonomian nasional. Dalam strategi memanfaatkan potensi, Cakera (2012) juga menjelaskan mengenai strategi untuk membangun perekonomian Indonesia yang harus digalakkan dengan pembangunan masyarakat berwirausaha, tak terkecuali di pedesaan.

Dalam rangka meningkatkan perekonomian desa perlu adanya pendidikan kewirausahaan kepada masyarakatnya untuk mengetahui dan memanfaatkan potensi desa. Tak hanya itu, pendidikan kewirausahaan yang dilakukan di desa juga berpotensi menciptakan iklim kondusif terhadap perekonomian nasional karena masyarakatnya yang mandiri, sehingga masyarakat desa memiliki SDM yang berkualitas. (Muthoifin, 2019)

Mengenai peningkatan SDM desa, diperlukan adanya pendekatan yang berbeda dengan kota. Seperti yang dicirikan oleh Sosiolog Selo Soemardjan (1993) bahwa masyarakat desa juga memiliki ciri, salah satunya adalah sistem sosial yang masih diwarnai 
dengan kesadaran kepentingan kolektif. Kepentingan ini diartikan dimana kepentingan bersama lebih diutamakan daripada kepentingan pribadi. Sifat kolektif ini yang menjadi alasan bahwa pendekatan pendidikan kewirausahaan memiliki cara yang berbeda dalam peningkatan SDM dan pengembangan kewirausahaan di desa.

Pengembangan kewirausahaan desa yang sedang digalakkan ini selaras dengan Visi 2025, yang diwujudkan melalui 3 (tiga) hal yaitu: 1. Peningkatan nilai tambah dan perluasan rantai nilai proses produksi serta distribusi dari pengelolaan aset dan akses (potensi) SDA, geografis wilayah, dan SDM, melalui penciptaan kegiatan ekonomi yang terintegrasi dan sinergis di dalam maupun antarkawasan pusat-pusat pertumbuhan ekonomi, 2 . Mendorong terwujudnya peningkatan efisiensi produksi dan pemasaran serta integrasi pasar domestik dalam rangka penguatan daya saing dan daya tahan perekonomian nasional, 3. Mendorong penguatan sistem inovasi nasional di sisi produksi, proses, maupun pemasaran untuk penguatan daya saing global yang berkelanjutan, menuju innovation driven economy. (Ray Septianis, 2013)

Kaitannya dengan pendidikan kewirausahaan desa, hal ini sudah dipraktikkan oleh masyarakat Desa Gerdu. Desa tersebut terletak di Kecamatan Karangpandan, Kabupaten Karanganyar. Lingkungan ini sebelumnya adalah sebuah desa tertinggal dan masyarakatnya awam terhadap kegiatan bisnis. Petani yang menjadi mata pencaharian utama membuat masyarakat disana hanya mengetahui tentang jual beli gabah saja, padahal ada sesuatu yang lebih besar daripada itu. Salah satu kendala besar dalam menaikkan ekonomi desa adalah karena rendahnya SDM. SDM di Desa Gerdu sangat minim pengetahuan tentang proses produksi, tidak mengerti keinginan pasar, serta tak memiliki strategi pemasaran yang baik. Selain itu, data Kecamatan Karangpandan (2018) Desa Gerdu yang memiliki populasi 3.225 jiwa terdapat jumlah petani terbesar di Karangpandan yaitu 1.502 jiwa.

$$
\text { Entoh Tohani et.al }
$$
menyebutkan, pendidikankewirausahaan masyarakat melalui berbagai bentuk diharapkan membentuk kemampuan wirausaha warga masyarakat baik secara individu maupun kelompok. Dalam pembentukkan kemampuan wirausaha warga secara kelompok, Desa Gerdu menawarkan sebuah solusi atas permasalahan di atas. Berawal dari keprihatian salah satu tokoh masyarakat disana, desa ini sanggup bertransformasi menjadi desa yang mandiri. Tak hanya itu, desa ini sekarang dikenal di taraf nasional.

Di sisi lain, ternyata fenomena desa tertinggal masih banyak terjadi di Indonesia, hanya berkisar $7 \%$ desa mandiri, sisanya adalah desa berkembang dan desa tertinggal (Badan Pusat Statistik Indonesia, 2018). Diantara penyebab masih banyaknya desa tertinggal adalah minimnya akses informasi, akses pelayanan dasar baik pemerintah pusat maupun daerah, kurangnya kesadaran warga desa akan potensi desa yang dimilikinya serta masih minimnya pemahaman warga desa akan pentingnya sifat kolektif dalam membangun desa itu sendiri.

Oleh karena itu, peneliti tertarik untuk menganalisa lebih dalam konsep ICE yang telah di contohkan oleh Desa Gerdu, dimana konsep ICE dapat menjadikan desa Gerdu mandiri bukan desa tertinggal lagi. Sehingga, selanjutnya hasil penelitian ini diharapkan dapat menjadikan referensi terpadu bagi desadesa tertinggal lainnya yang masih banyak 
tersebar di seluruh Indonesia Adapun strategi dan proses pelaksanaannya di Desa Gerdu,serta keefektifan ICE sebagai solusi desa tertinggal akan dijelaskan dalam hasil penelitian.

\section{METODOLOGI PENELITIAN}

Jenis penelitian ini termasuk dalam penelitian lapangan (field research) karena penelitian ini dilakukan secara sistematis dengan mengangkat data di lapangan. Pendekatan dalam penelitian ini adalah deskriptif kualitatif. Pada penelitian ini, penulis menerapkan model studi kasus yang faktual dan akurat mengenai fenomena di masyarakat dengan hasil berupa kata-kata. Subjek dalam penelitian ini adalah:

1. Tokoh masyarakat Desa Gerdu,

2. Karang Taruna Desa Gerdu,

3. BAZNAS Kabupaten Karanganyar.

Adapun objek dalam penelitian ini adalah konsep ICE dalam memjawab permasalahan ekonomi di Desa Gerdu. Metode pengumpulan data dilakukan dengan wawancara, observasi dan dokumentasi.

\section{HASIL DAN PEMBAHASAN Desa Tertinggal}

Kartohadikoesoemo (1982) desa secara etimologi berasal dari kata bahasa sanskerta "deshi" yang berarti tanah kelahiran (mother land). Sedangkan dalam terminologi kontemporer, desa memiliki keragaman makna. Moore (1981) memberikan variasi dari keberagaman definisi dengan melihat karakteristik pencirinya (yang membedakannya dengan terminologi kota), yaitu: 1. Desa dalam konteks kondisi ekologis dan landscape, 2. Jumlah dan kepadatan penduduk, 3.. Pola aktivitas ekonomi, 4. Fungsi ekonomis dalam konteks geografiekonomi, 5. Pola interaksi masyarakat.
Secara faktual, pemberian istilah pada masyarakat pedesaan sering digambarkan sebagai suatu kelompok masyarakat yang bertumpu pada aktivitas cenderung kolektif dimana basis aktivitasnya bersumber dari alam seperti, pertanian dan keragaman hayati.

Namun demikian, kekayaan alam yang ada di desa tidak berbanding lurus dengan sumber daya manusia yang ada di Desa, sebagian besar penerusnya lebih memilih meninggalkan desa, sehingga mengakibatkan kekayaan alam tersebut tidak dapat dimanfaatkan dengan baik dan tertinggal begitu saja. (Badan Pusat Statistik Indonesia, 2019)

Desa Tertinggal yaitu desa yang mempunyai ketersediaan dan akses terhadap pelayanan dasar, infrastruktur, aksesibilitas/transportasi, pelayanan umum, dan penyelenggaraan pemerintahan yang masih minim. Secara teknis, desa tertinggal merupakan desa yang memiliki nilai IPD kurang dari atau sama dengan 50.

IPD atau Indeks Pembangunan Desa diperoleh dari penjumlahan secara tertimbang terhadap setiap Indikator penyusun IPD. Nilai yang dijumlahkan adalah skor setiap indikator yang sudah ditimbang/dikalikan dengan penimbang masing-masing indikator. Indikatorindikator tersebut terdiri dari ketersediaan dan akses terhadap pelayanan dasar, infrastruktur, aksesibilitas/transportasi, pelayanan umum, dan penyelenggaraan pemerintahan.

Badan Pusat Statistik Indonesia (2018) telah menghitung indeks desa tertinggal masih sebanyak $17,96 \%$ atau masih ada 13.232 desa tertinggal dan telah berkurang sebanyak 9,578\% dari tahun 2014 yang masih berkisar 26,81 \%. Hal tersebut dapat dibuktikan dari table di bawah ini: 


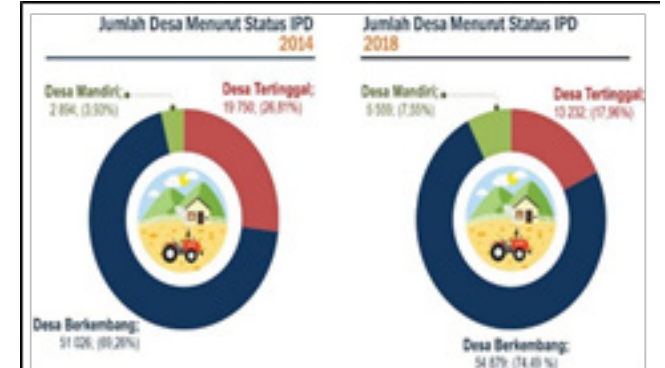

Gambar 1. Perkembangan Pembangunan Desa Menurut Status Indeks Pembangunan Desa, 2014 dan 2018

Dari gambar diatas dapat diketahui bahwa pada tahun 2018 desa berkembang menduduki prosentasi terbanyak yaitu sebesar 54.879 atau $74,49 \%$ dari jumlah seluruh desa di Indonesia. Menurut Badan Pusat Statistik Indonesia (2018) desa berkembang yaitu desa yang mempunyai ketersediaan dan akses terhadap pelayanan dasar, infrastruktur, aksesibilitas/ transportasi, pelayanan umum, dan penyelenggaraan pemerintahan yang cukup memadai. Secara teknis, desa berkembang merupakan desa yang memiliki nilai IPD lebih dari 50 namun kurang dari atau sama dengan 75 .

Namun demikian, untuk memajukam perekonomian Indonesia diperlukan prosentasi desa mandiri yang besar, tapi kenyataannya desa tertinggal masih sangat berbanding jauh dengan desa mandiri yaitu sebanyak $7,55 \%$ atau 5559 desa banding 17,96\% atau 13.232 desa tertinggal. Prosentase tersebut tak lain menyatakan bahwa Indonesia masih harus berusaha meningkatkan desa yang mandiri untuk meningkatkan kualitas dan taraf kehidupan yang lebih baik bagi warga negara Indonesia. Menurut Badan Pusat Statistik Indonesia (2018) desa mandiri adalah desa yang mempunyai ketersediaan dan akses terhadap pelayanan dasar yang mencukupi, infrastruktur yang memadai aksesibilitas/ transportasi yang tidak sulit, pelayanan umum yang bagus serta penyelenggaraan pemerintahan yang sudah sangat baik. Secara teknis, desa mandiri merupakan desa dengan nilai IPD lebih dari 75.

Indeks Pembangunan Desa (IPD) lebih dari 75 artinya perekonomian desa mandiri telah dapat menjadi tulang punggung perkeonomian nasional Indonesia. Salah satu langkah yang perlu dilakukan adalah dengan mefokuskan pendidikan pada kewirausahaan yang bersifat kolektif atau gotong royong antar masyarakat desa guna meningkatkan kualitas dan ke-efektifan dalam berwirausaha.

\section{Islamic Entrepreneurship}

Islamic Entrepreneurship atau kewirausahaan dalam Islam (Wigati, 2015: 156) tidak menjelaskannya secara eksplisit melainkan digunakan dengan kata kerja keras, kemandirian (biyadihi), dan tidak mudah menyerah. Dalam Al-Qur'an, kata Wirausaha digunakan dengan kata Tijarah yang berarti pembelian barang di satu pasar dan menjualnya kepada orang lain. Dalam prakteknya, kewirausahaan dalam Islam merujuk pada kewirausahaan Rasulullah dan memiliki etika-etika Islam, diantaranya adalah:

a. Menjadikan bekerja sebagai ladang menjemput surga. Semua pekerjaan yang menghasilkan rizki dan dimanfaatkan untuk memberikan nafkah keluarga dan disedekahkan kepada fakir miskin

b. Kejujuran dan kepercayaan menjadi modal utama Rasul. Adanya kejujuran dan kepercayaan Rasul yang memimpin kafilah menyusuri Yaman, Syam, Madyan membawa barang dagangan Khadijah dan meraih untung besar.

c. Tidak cuma mimpi, tetapi harus jago mewujudkan mimpi. Mimpi menjadi kaya sering dialami semua orang, tapi tidak semua orang gigih untuk mewujudkan mimpi menjadi kenyataan. Sedangkan Rasulullah 
mampu mewujdkan semua mimpi dan angan.

d. Berpikir visioner, kreatif, dan siap menghadapi perubahan. Dalam hal ini memegang prinsip reputasi, tumbuh dari bawah, anti kerumunan, modal hanya pelengkap. Selain hal tersebut butuh skill interpersonal, leadership dan managerial.

Dari yang telah disebutkan di atas, kewirausahaan Islam yang dijelaskan terlebih kepada etika-etika yang telah dipraktikkan oleh Rasulullah SAW ketika berdagang.

\section{Konsep Islamic Collective Entrepreneurship}

Kewirausahaan diartikan lebih kepada perilaku, sikap, dan semangat. Sederhananya, kewirausahaan adalah etos dalam berbisnis. Sedangkan kewirausahaan dalam setiap peradaban, agama, dan budaya manusia memiliki cara yang berbeda-beda, salah satunya dalam agama Islam. Dalam etika bisnis Islam, kewirausahaan Islam menjadi dasar bagi tiap individu Muslim yang telah diajarkan oleh Rasulullah saat berdagang.

Ekspansi dakwah Islam termasuk ajaran kewirausahaan Islam yang menembus budaya-budaya dan gaya hidup yang berbeda, disertai dengan perkembangan teknologi dan informasi yang ada. Hal tersebut mengakibatkan adanya upaya-upaya inovasi dalam ajaran bermuamalah dalam Islam, salah satunya kehidupan bermuamalah di Indonesia. Kehidupan Islam dalam bermuamalah di Indonesia juga merupakan hasil dari akulturasi antara ajaran Islam dan budaya Indonesia. Salah satu budaya Indonesia yaitu bergotong-royong atau melakukan hal yang kolektif merupakan ciri khas gaya hidup di Indonesia. (Muthoifin, 2016)

Penggabungan antara budaya Indonesia dan ajaran Islam melahirkan suatu konsep ICE (Islamic Collective Entrepreneurship)dalamhalberwirausaha dan kegiatan ekonomi, konsep ini merupakan hasil perpaduan ajaran Islam seperti Islamic Entrepreneurship (Kewirausahaan Islam) dan Collective (Kolektif) atau disebut gotong-royong. Konsep ini juga dipraktikkan dimana desa yang memiliki warga yang mayoritas beragama Islam seperti halnya Desa Gerdu. Dapat disimpulkan Islamic Collective Entrepreneurship (ICE) atau kewirausahaan kolektif Islam adalah Kewirausahaan yang bersifat kolektif dan berbasis gotong royong dengan etikaetika dalam ajaran islam.

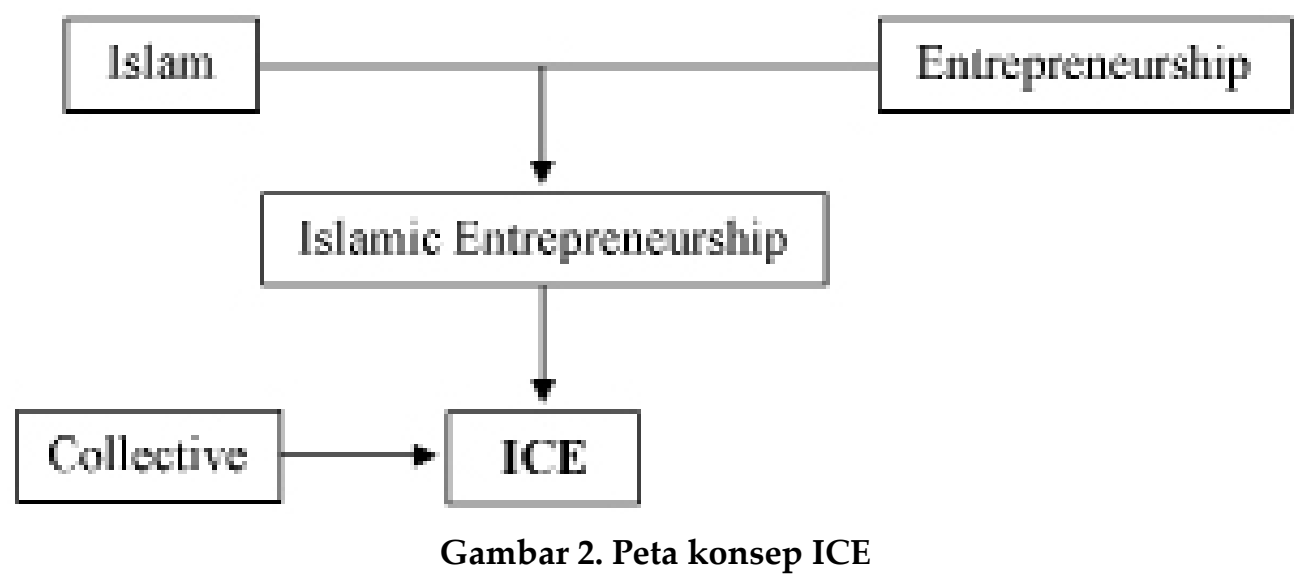


Proses Pelaksanaan ICE di Desa terhadap pembangunan Desa Gerdu, Gerdu

desa tersebut masih stagnan dalam

Proses yang dilakukan dalam kurun waktu sekitar satu setengah tahun untuk membangun Desa Gerdu. Dalam proses ini memiliki beberapa tahap, diantaranya adalah:

a. Persiapan (Pendidikan dan

Kerjasama)

Dimulai dari kepedulian tokoh perkembangan ekonominya terutama dalam produksi pertanian. Sebelumnya masyarakat desa secara umum masih mengetahui Islam hanya sebatas Aqidah ataupun Akhlak, sedangkan pengetahuan dalam ekonomi Islam dan pelaksanaannya masih belum mendalam. pondok pesantren sekaligus tokoh desa

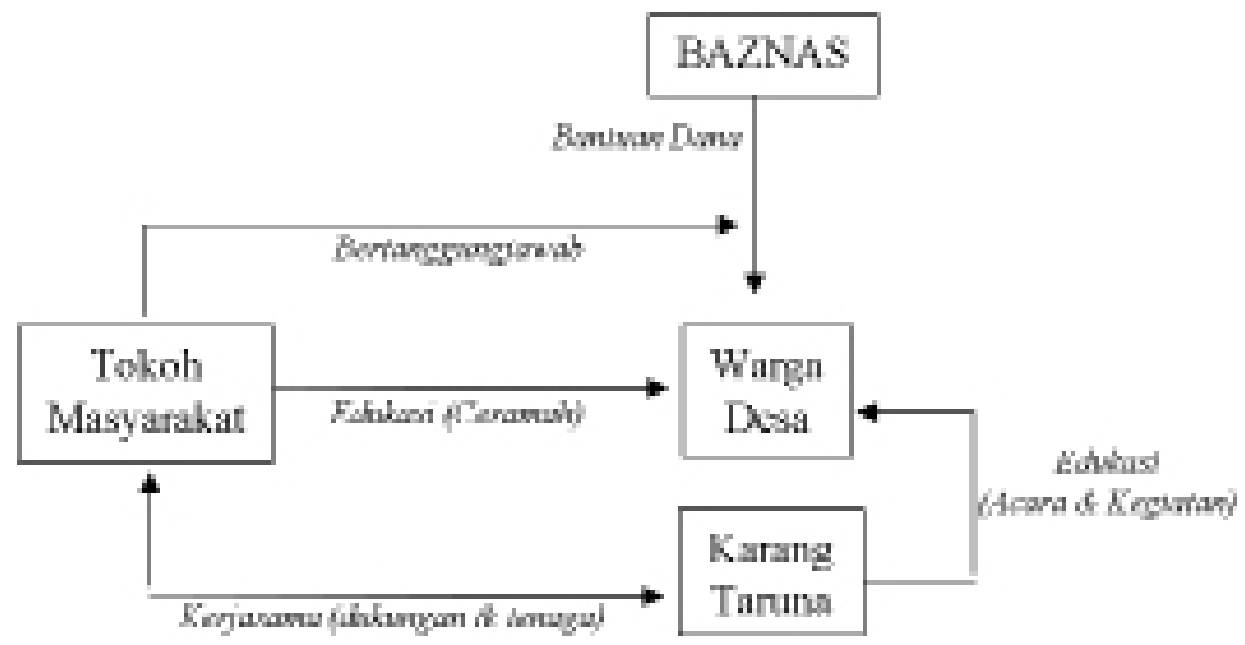

Gambar 3. Skema proses pelaksanaan ICE

Dalam proses sosialisasi ekonomi Islam selama empat tahun, dakwah dan pengajaran mengenai ekonomi Islam disertai dengan kewirausahaan Islam terhadap warga Desa Gerdu, seperti musyarakah, syirkah, larangan riba, dan sebagainya. Sosialisasi tersebut masih sebatas melalui ceramah dan disampaikan secara teori saja. Efek yang dihasilkan masih belum berhasil dilakukan secara praktik dan tidak ada pelaksanaan oleh warga.

Dari efek tersebut, tokoh pondok pesantren mengajak Karang Taruna dan bekerjasama untuk membantu melaksanakan praktik kewirausahaaan Islam di Desa. Karena Karang Taruna desa tersebut yang memiliki massa dan etos yang aktif dalam melakukan kegiatan. Di samping itu, latar belakang beberapa anggota Karang Taruna desa yang sedang mengenyam pendidikan tinggi (Universitas) maupun pondok pesantren, sehingga mereka memiliki kesadaran tinggi tentang hasil yang progresif apabila program tersebut dilaksanakan.

Kerjasama ini tidak hanya dilakukan oleh tokoh pondok pesantren dan Karang Taruna. Tokoh desa seperti kepala dukuh, RT, dan RW di Gerdu juga mendukung dan bergotong-royong untuk membantu perencanaan tersebut dapat direalisasikan.

Dari pihak eksternal, kerjasama juga dilakukan dengan BAZNAS (Badan Amil Zakat Nasional) Karanganyar. BAZNAS Karanganyar yang memiliki program 'Desa Barokah', dimana desadesa yang ada di kawasan Karanganyar dibantu dalam pelaksanaan membangun desa melalui dana, salah satunya Desa Gerdu. Mengenai hal tersebut, tokoh 
pondok pesantren dan tokoh desa menjadi penanggungjawab kerjasama yang dilakukan antara BAZNAS dan Desa Gerdu. Di samping itu, sosialisasi zakat juga dilakukan oleh pihak Pondok Pesantren Iskarimah berkerjasama dengan BAZNAS kepada warga desa.

Selain kerjasama yang dilakukan, persiapan untuk dapat mengajak warga secara keseluruhan diadakan acara-acara yang disertai dengan edukasi dalam hal kewirausahaan dengan dukungan Karang Taruna setempat. Hal ini disebabkan karena warga desa lebih tertarik terhadap acara yang bersifat kolektif atau kebersamaan.
Untuk mengembangkan Sumber Daya Manusia dalam lingkungan desa, juga diadakan pelatihan-pelatihan bagi warga. Salah satunya pengiriman kader Karang Taruna untuk studi banding ke Malang (Usaha Restoran), Selo Merbabu (Peternakan), dan Jember (Pertanian). Setelah melakukan studi banding, pengajaran dilakukan kepada warga desa.

b. Proses (Pelaksanaan dan Pengelolaan) Proses Pelaksanaan dan pengelolaan yang dilakukan di Desa Gerdu memiliki beberapa sektor program diantaranya adalah:

Tabel 1. Pelaksanaan dan pengelolaan

\begin{tabular}{|c|c|c|c|}
\hline No. & Program Pelaksanaan & & Pengelolaan \\
\hline 1. & Pertanian & $\begin{array}{l}\text { 1) } \\
\text { 2) } \\
\text { 3) }\end{array}$ & $\begin{array}{l}\text { Menjadikan lahan mati menjadi Uji coba } \\
\text { Membuat kolam untuk peternakan lele dan penampungan } \\
\text { air untuk sawah-sawah } \\
\text { Menghidupkan lahan mati dengan sawah- sawah dari } \\
\text { pengairan kolam baru } \\
\text { Pertanian dari sawah yang baru dilakukan tanpa pestisida }\end{array}$ \\
\hline 2. & Kampung Wisata & $\begin{array}{l}\text { 1) } \\
\text { 2) }\end{array}$ & $\begin{array}{l}\text { Pembangunan Restoran saung dan rekreasi keluarga } \\
\text { Pembangunan taman di alun-alun desa dan rumah- } \\
\text { rumah warga }\end{array}$ \\
\hline 3. & Kampung Bahasa & $\begin{array}{l}\text { 1) } \\
\text { 2) } \\
\text { 3) }\end{array}$ & $\begin{array}{l}\text { Program Kursus Bahasa Arab } \\
\text { Tenaga Pendidik berasal dari pondok } \\
\text { Sarana-prasarana dengan bantuan warga desa }\end{array}$ \\
\hline
\end{tabular}

1) Pertanian

Pendekatan untuk mempraktikkan program yang dilakukan pertama adalah sektor pertanian, karena Desa Gerdu masih didominasi mata pencaharian di sektor Pertanian dan profesi Petani terbesar di Kecamatan Karangpandan. Di samping itu banyaknya lahan yang mati menjadikan ujicoba pertama dalam berinovasi di Desa Gerdu.

Inovasi tersebut dilakukan dengan membuat kolam untuk peternakan lele dan penampungan air untuk sawahsawah apabila terjadinya kemarau. Pembuatan kolam ini dilakukan dengan bergotongroyong atau kolektif. Di samping itu, menghidupkan lahan mati menjadi sawah baru juga dilakukan yang mana air dari sawah berasal dari kolam-kolam yang dibuat. Proses kepemilikan lahan baru dilakukan dengan Ujroh Musyarakah antar warga yang ikut serta dalam melakukan program ini. 
Program ini tidak hanya dilakukan dengan pembuatan kolam, melainkan juga program bertani di lahan baru tanpa menggunakan pestisida. Tujuan tersebut untuk menggalakkan hasil pertanian yang organik, lebih cepat panen, dan menyehatkan lahan yang bebas pestisida. Adapun cara yang dilakukan dalam program pertanian ini secara bertahap, agar dapat meyakinkan warga petani untuk ikut melakukan hal tersebut.

2) Kampung Wisata

Letak Desa Gerdu yang didominasi area persawahan dan kontur perbukitan, menjadikan ide untuk membangun restoran saung dan area rekreasi keluarga yang terletak di bagian dukuh Pakel. Ide ini menjadi titik awal permulaan untuk menjadikan desa Gerdu sebagai Kampung Wisata.

Pelaksanaan pembangunan dilakukan dengan gotongroyong antar warga. Akad yang dilakukan dalam restoran saung dilakukan dengan syirkah dan pembagian laba yang dilakukan secara adil dan selalu adanya monitoring antar warga. Selain itu budaya bisnis yang dibangun dilakukan dengan kekeluargaan dalam hal perencanaan usaha yang akan dilakukan.

Tidak hanya restoran saung, pembangunan taman yang berada pada alun-alun desa juga dilakukan secara kolektif dalam rangka mewujudkan kampung wisata. Pembangunan taman mini pada perkarangan warga juga digalakkan untuk memperindah desa.
3) Kampung Bahasa

Kampung bahasa dilakukan dengan adanya dukungan dan kerjasama dari pondok pesantren. Dimana menitikberatkan kepada bahasa Arab sebagai program kursus yang dilakukan. Pihak yang mengajar berasal dari pondok pesantren Iskarimah, sedangkan pihak warga yang bertugas dalam menyediakan sarana-prasarana seperti bangunan, alat-alat pendukung, dan lain-lain. Program ini dilakukan dengan berbayar dengan bagi hasil.

Dari program-program yang dilaksanakan terutama dalam hal pendidikan kewirausahaan Islam bergotong-royong atau konsep ICE yang dilaksanakan di Desa Gerdu secara bertahap, dimana praktik yang dilakukan adalah edukasi dan sampling yang bertujuan untuk memberikan contoh dan mengajak warga yang belum ikut, serta dapat diyakini dengan contoh yang telah berhasil.

Selain pelaksanaan program yang dilakukan untuk berwirausaha, program yang bertujuan untuk sosial seperti program zakat 'Baitul Mal Mulia' juga dilaksanakan pengumpulan zakat dalam desa setiap sebulan sekali. Program tersebut akan digunakan untuk membantu keluarga yang tidak mampu dalam desa. Apabila dana zakat yang dikeluarkan memiliki kelebihan, maka akan dibagikan ke desa lain.

\section{c. Hasil (Evaluasi dan Perencanaan)}

Dari proses yang telah dilakukan secara bertahap dalam kurun waktu satu 
setengah tahun, memiliki perubahan yang progresif bagi warga. (Lihat tabel 2) Pertama, lahan baru yang menjadi uji coba memiliki hasil panen yang lebih cepat dan berkualitas baik, percobaan ini sudah dilakukan dua kali.

Kedua, terwujudnya kampung wisata yang bernuansa Islam menjadi suatu perubahan besar bagi Desa Gerdu. Kedua, terwujudnya kampung bahasa menjadikan pemasukkan ekonomi bagi warga dan mendidik anak-anak di Desa Gerdu seputar bahasa. Di samping banyaknya turis yang berdatangan, hal ini juga berefek dalam meningkatkan ekonomi warga melalui kewirausahaan dan semangat menjalankan keislaman dengan bermuamalah.

Mengenai perencanaan, dalam sektor pertanian salah satu program yang direncanakan yaitu BMT (Baitul Maal wa Tanwil) akan dibangun di Desa Gerdu untuk memperlancar usaha-usaha warga terutama dalam bidang Pertanian.
Selain itu juga, rencana ini juga menjadi salah satu praktik dan sarana edukasi langsung bagi warga untuk menghindari riba dalam bermuamalah. Tidak hanya itu, perencanaan mengenai pertanian yang telah berhasil diuji coba secara perlahan diikuti oleh petani-petani lain. Dalam sektor kampung wisata juga akan dibangun sarana-sarana dalam wisata baru semisal restoran dan penginapan. Dalam sektor kampung bahasa direncanakan akan menambah program bahasa lain, seperti bahasa Inggris.

Evaluasi program yang sedang berjalan dan program yang telah berjalan dilakukan dengan pendampingan dan pengawasan baik pihak internal (Karang Taruna, warga, kepala desa, kepala dukuh, RT, dan RW) maupun pihak eksternal seperti BAZNAS dan pihak Pondok Pesantren yang turut serta dalam membangun desa. Terlebih proses evaluasi dilakukan dengan saling koordinasi antar pihak terkait.

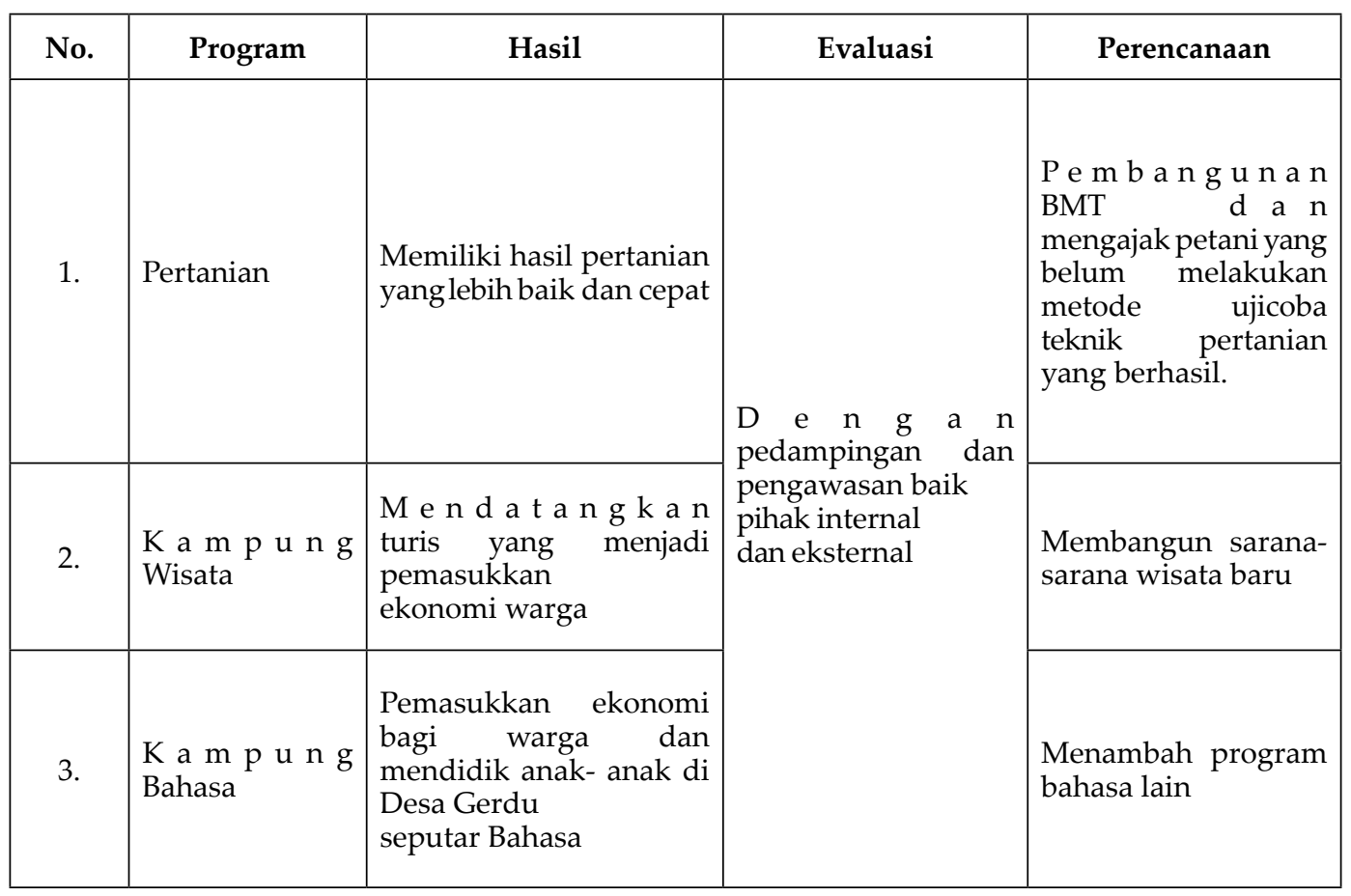

Kefektifan ICE Sebagai Solusi faktor pendukung dimana konsep ini Mengatasi Desa Tertinggal Dalam dapat terlaksanakan. Pertama, desa ini praktik pelaksanakan konsep ICE di memiliki geografis berdekatan dengan Desa Gerdu terdapat beberapa faktor- pondok pesantren. Tokoh dan pihak- 
pihak pondok pesantren yang bertempat tinggal di Desa Gerdu juga melakukan pendakwahan dan kontak sosial dengan warga, sehingga warga desa secara umum memiliki budaya Islam yang religius. Kedua, adanya keaktifan, etos, dan inisiatif pada pemuda-pemudi Karang Taruna desa yang terus berupaya untuk meningkatkan taraf hidup warga desa. Ketiga, adanya kolaborasi dan budaya kolektif dari seluruh pihak yang mengakibatkan adanya saling mendukung dalam membangun desa. Oleh karena itu, konsep ICE yang dilakukan sangat diperlukan adanya pihak-pihak yang berkolaborasi, aktif, dan saling mendukung.

Proses pelaksanaan yang dilakukan di Desa Gerdu, dimana budaya kolektif atau gotong-royong yang telah ada pada desa, dapat dimasukkan nilai-nilai Islam terutama nilai kewirausahaan Islam. Hal ini mengakibatkan adanya rasa kebersamaan untuk melakukan perubahan serta dakwah bersama. Dakwah tersebut tidak hanya sebatas teori, melainkan lebih kepada praktik langsung yang mana dilakukan secara bertahap melalui cara edukasi dan sampling.

Cara ini bertujuan untuk membuktikan keberhasilan suatu program dan meyakinkan warga agar dapat mengikuti cara tersebut. Hal ini juga menjadi suatu tips dalam mendidik warga tentang pendidikan ekonomi syariah, yang mana warga juga melakukan dan merasakan langsung akibat positif yang ditimbulkan dari praktik ekonomi syariah terutama kewirausahaan islam.

Konsep ICE juga didorong dari warga desa yang memiliki latar belakang yang sama. Karena konsep ICE yang merupakan etos dasar untuk melangkah bersama dan perubahan yang dilakukan untuk dapat meminimalisir resiko dan hambatan yang ada, sehingga solidaritas desa yang terbangun karena memiliki kesamaan latar belakang dan etos menjadikan praktik konsep ICE dapat efektif dilakukan.

\section{PENUTUP}

Konsep ICE juga didorong dari warga desa yang memiliki latar belakang yang sama. Karena konsep ICE yang merupakan etos dasar untuk melangkah bersama dan perubahan yang dilakukan untuk dapat meminimalisir resiko dan hambatan yang ada, sehingga solidaritas desa yang terbangun karena memiliki kesamaan latar belakang dan etos menjadikan praktik konsep ICE dapat efektif dilakukan.

\section{DAFTAR PUSTAKA}

Agusta, Ivanovich dan Fujiartanto (ed). 2014. Indeks Kemandirian Desa: Metode, Hasil dan Alokasi Program Pembangunan. Jakarta: Departemen Sains Komunikasi dan Pengembangan Masyarakat, Fakultas Ekologi Manusia, IPB dengan Yayasan Pustaka Obor Indonesia

Arikunto, Suharismi. 1995. Dasar - Dasar Research. Bandung: TarsotBadan Pusat Statistik (BPS), 2018.

CnbcIndonesia.com."Jokowi Sudah Gelontorkan Dana Desa Rp 189 T b Efektifkah? Diakses pada 31 Mei 2019:

https://www.cnbcindonesia.com/news/20190531141241-4-76159/jokowi-sudahgelontorkan-dana-desa-rp-189-t-efektifkah

Kartohadikoesoemo S. 1982. Desa. Jakarta: Balai Pustaka 
Prastiwi, Dwi Agus, dkk. 2019. Indeks Pembangunan Desa 2018. Jakarta: Badan Pusat Statistik Indonesia

Kusnaedi. 2006. Membangun Desa. Jakarta: Penebar Swadaya

MPR Indonesia. 2001. Tap Mpr No Vi/Mpr/2001 Tentang Etika Kehidupan Berbangsa. Jakarta

Muthoifin, Politik Otonomi Daerah Dalam Bingkai Islam dan Keindonesiaan, Proseding The 3rd University Research Colloquium 2016.

Muthoifin, Pembinaan Kerukunan Masyarakat Baru Pada Perumahan Baru Perum Griya Salaam Boyolali, Proseding The 10th University Research Colloqium 2019 Sekolah Tinggi Ilmu Kesehatan Muhammadiyah Gombong

Rizal, Hamdani Syamsul. 2019. Kewirausahaan. Ponorogo: Uwais

Septianis, Ray. 2013. “Peluang Mengembangkan Kewirausahaan Desa Berbasis Potensi Desa (Studi Deskriptif di Desa Karang Rejo Kecamatan Negeri Katon Kabupaten Pesawaran, Kampung Suka Jawa Kecamatan Bumi Ratu Kabupaten Lampung Tengah dan Desa Sidoasri Kecamatan Candi Puro Kabupaten Lampung Selatan Propinsi Lampung)". Jurnal Bina Praja. Vol. 5 No. 4

Soemardjan, Selo, dkk. 1993. Masyarakat dan Manusia Dalam Pembangunan:Pokok- pokok Pikiran Selo Soemardjan. Jakarta: Pustaka Sinar Harapan

Tohani, Entoh, dkk. 2015. "Pendayagunaan Modal Sosial dalam Pendidikan Kewirausahaan Masyarakat: Studi pada Program Pendidikan Desa Vokasi". Jurnal Pembagunan dan Pendidikan. Vol. 3 No. 2

Usman, Husaini. 1996. Metodologi Penelitian Sosial. Jakarta: Sinar Grafika Offset Widiawaty, Millary A. 2019. Faktor-faktor Urbanisasi di Indonesia. UPI: Bandung Wigati, Sri. 2015. Kewirausahaan Islam (Aplikasi dan Teori). UIN: Surabaya Widjaja. 2004. Otonomi Desa. Jakarta: Rajawali Pers

Yunus, Hadi Sabari. 2010. Metodologi Penelitian Wilayah Kontemporer.

Yogyakarta: Pustaka Pelajar.

Zulkarnaini; Triyanto, Neillis. 2010. Perubahan Sikap dan Perilaku Gotong Royong pada Masyarakat Gampong Keub Pasca Tsunami Aceh 2004. Meulaboh: Universitas Teuku Umar. Undang - undang Nomor 25 Tahun 2004 Tentang Sistem 